\title{
A first approach to a faunistic crenon typology based on functional feeding groups
}

\author{
Stefanie VON FUMETTI* and Peter NAGEL \\ University of Basel, Institute of Biogeography, Department of Environmental Sciences, St. Johanns-Vorstadt 10, 4056 Basel, \\ Switzerland \\ *e-mail corresponding author: stefanie.vonfumetti@unibas.ch
}

\begin{abstract}
Springs are ecomorphologically and faunistically diverse freshwater ecosystems. Their limnological classification has been a focus of interest since crenic research began. Despite many attempts to include the crenic fauna in the classification of springs, there is no faunistic crenon typology. Over a three-year period we investigated the macroinvertebrate assemblages and the physical, chemical and ecomorphological conditions of 82 springs in the Swiss Jura Mountains, north-western Switzerland. Based on these data we selected the 25 least-disturbed springs to develop a faunistic crenon classification. Based on functional feeding groups we differentiated three crenon groups. An analysis of similarities and nonmetric multidimensional scaling for the substratum types supported the crenon groupings. In general we can distinguish between springs that are dominated by scrapers and characterized by a lotic environment, and those that are mostly inhabited by filtering collectors, associated with a lentic environment. Those two crenon types are the extremes of a continuum. Particular crenon forms, such as those with extensive carbonate deposits, lie between these extremes. This third group is characterized by gathering collectors and shredders. Using this approach we can distinguish faunistic crenon types, based on functional feeding groups, which reflect the abiotic conditions within the springs. We provide a foundation for a faunistic crenon typology which now can be tested in other landscapes and will then be applicable to other low mountain ranges in Europe.
\end{abstract}

Key words: macroinvertebrates, faunistic classification, lotic springs, lentic springs

\section{INTRODUCTION}

Springs are unique ecosystems with specific abiotic conditions (Odum 1971; van der Kamp 1995) which are inhabited by specially adapted organisms (e.g., Williams \& Danks 1991; Ferrington 1995). Since the start of limnological research springs have been a focus of interest. Most studies were conducted in lower mountain ranges (e.g., Thienemann 1912; Beyer 1932) or lowlands of North Germany (e.g., Thienemann 1923, 1926). But studies from southern German (Zschokke 1902) and pre-Alpine lower mountain ranges (Bornhauser 1912; Chappuis 1924; Geijskes 1935) also exist from this time. The need for a classification of springs soon became obvious, and the habitat-related morphological types, rheocrene, helocrene, and limnocrene, were defined by Steinmann (1915) and Thienemann (1924). Since then, many other crenon typologies have been developed for different mid-European regions, based on ecomorphological features (Beyer 1932; Schwoerbel 1959; Gerecke 1991), chemical factors (Roca 1990), or physical and chemical parameters, and macrozoobenthic communities (Williams et al. 1997; Hahn 2000). Faunistic elements (Gerecke \& Di Sabatino 1996), diatom microflora (Cantonati 2004) or whole macrofaunal species assemblages (Gauterin 1999; Zollhöfer et al. 2000; Martin et al. 2008) have also been included in ecomorphological classifications.
As an Alpine country with high precipitation and therefore a large groundwater reservoir, Switzerland is especially rich in crenic ecosystems. Few springs, however, remain in their natural or at least near-natural condition. For example in north-western Switzerland only a minimum number of the springs are still natural (Zollhöfer 1997). Despite their importance as habitats for specialized species and despite their endangered situation there are only a few current studies on natural springs in Switzerland (e.g., Baltes et al. 2006; von Fumetti et al. 2006). Most knowledge derives from a study conducted by Zollhöfer (Zollhöfer 1999; Zollhöfer et al. 2000), who developed an ecomorphological crenon typology based on the classification of Steinmann (1915) and Thienemann (1924).

The trophic relationships in springs were mostly studied in the middle of the 20th century (e.g., Odum 1957; Teal 1957; Tilly 1968), before the trophic structuring of communities based on functional feeding groups had been devised by Cummins (1973). These early studies looked at single springs; comparisons of different functional feeding groups in different springs are almost lacking. Based on the River Continuum Concept (Vannote et al. 1980) we would generally expect shredders to domintate the upper part of river ecosystems with a high input of allochthonous material as the most important food source for shredders.

The present study was part of the Basel Spring Project (Baltes et al. 2005) conducted in north-western 
Tab. 1. Temperature and discharge range, dominant substratum and number of faunistic samples forthe 25 investigated springs; n. m. = not measured; FPOM = Fine Particulate Organic Matter; No. = number.

\begin{tabular}{|c|c|c|c|c|c|}
\hline Spring & $\begin{array}{c}\text { Swiss } \\
\text { coordinates }\end{array}$ & $\begin{array}{c}\text { Temperature } \\
{\left[{ }^{\circ} \mathrm{C}\right]}\end{array}$ & $\begin{array}{l}\text { Discharge } \\
{\left[\mathrm{L} \mathrm{min}{ }^{-1}\right]}\end{array}$ & Dominating substrata & $\begin{array}{c}\text { No. of faunistic } \\
\text { samples }\end{array}$ \\
\hline Q1 & $619.750 / 260.350$ & $7.9-10.2$ & n. m. & Calcareous tufa, leaves & 16 \\
\hline Q3 & $619.200 / 260.250$ & $8.7-9.9$ & $13-83$ & Calcareous tufa, bryophytes, leaves & 16 \\
\hline Q4 & $618.920 / 260.290$ & $9.9-10.8$ & $26-163$ & Sand, gravel & 12 \\
\hline Q57 & 617.775/259.625 & $8.3-10.3$ & $15-172$ & Gravel, stones & 12 \\
\hline Q59a & $619.150 / 260.325$ & $9.8-12.1$ & $17-150$ & Gravel, dead wood & 16 \\
\hline Q59b & $619.150 / 260.325$ & $9.8-12.1$ & $17-150$ & Gravel & 16 \\
\hline Q59c & 619.150/260.325 & $9.8-12.1$ & $17-150$ & Gravel, dead wood, stones & 16 \\
\hline Q61a & $618.525 / 259.950$ & $7.7-11.8$ & $2-134$ & Clay/silt, FPOM, leaves & 12 \\
\hline Q61b & 618.525/259.925 & $8.0-10.5$ & $2-91$ & Leaves, dead wood, gravel & 12 \\
\hline Q62 & 619.300/260.325 & $6.9-12.0$ & $4-91$ & Leaves, calcareous tufa & 12 \\
\hline Q63 & $617.825 / 259.650$ & $8.3-10.5$ & $2-122$ & Leaves, dead wood, stones & 8 \\
\hline Q64 & $617.550 / 259.550$ & $6.5-11.5$ & $1-156$ & Leaves, FPOM, calcareous tufa & 8 \\
\hline erl & $624.275 / 263.725$ & $1.5-12.7$ & $<1$ & Leaves, clay/silt & 12 \\
\hline non & $624.875 / 263.525$ & $4.2-11.2$ & $2-3$ & Leaves, clay/silt & 20 \\
\hline dam & $633.250 / 260.000$ & $7.5-16.1$ & $5-48$ & Clay/silt & 8 \\
\hline isch & $630.550 / 256.725$ & $7.4-10.2$ & 2 & Leaves, wood, calcareous tufa & 8 \\
\hline chr1 & $634.050 / 252.100$ & $8.0-10.6$ & n. m. & Sand, small stones & 8 \\
\hline chr2 & $632.950 / 253.050$ & $5.3-11.8$ & $32-54$ & Small stones & 8 \\
\hline flu & $636.775 / 252.025$ & $7.6-10.2$ & $2-95$ & Gravel, small stones & 8 \\
\hline düb & $637.275 / 258.725$ & $4.0-12.1$ & n. m. & Bryophytes, roots, calcareous tufa & 8 \\
\hline gor & $618.900 / 251.375$ & $7.0-8.5$ & $1-2$ & Leaves, clay/silt & 8 \\
\hline lup & $619.500 / 256.000$ & $9.0-12.0$ & 6 & Sand, gravel & 8 \\
\hline tbr & $603.975 / 251.000$ & $9.0-11.4$ & n. m. & Leaves, sand, garvel & 8 \\
\hline grei & $601.350 / 251.400$ & $7.4-9.3$ & n. m. & Leaves, FPOM, clay/silt & 8 \\
\hline mari & $604.100 / 258.275$ & $6.8-10.8$ & $42-210$ & Small stones, calcareous tufa & 12 \\
\hline
\end{tabular}

Switzerland 2003-2005. Eighty two springs were studied by hydrologists and biologists over several years. This gave us the opportunity to select natural, almost undisturbed springs, all emerging from the same geological substratum. Given these shared prerequisites, we tested whether springs can be classified faunistically, independent of the geomorphological features of the springs. Our goal was to develop a faunistic crenon typology based on functional feeding groups for a European low mountain range, which will form the foundation for a general crenon typology applicable to other parts of Europe.

\section{METHODS}

\subsection{Study area}

The study was conducted in the Swiss Jura Mountains, mainly the Tabular Jura. Twelve springs were situated in the Röseren valley, a small, relatively undisturbed valley near Basel, which has been intensively investigated, faunistically and hydrologically, over the years (Geijskes 1935; Küry 1997; Butscher \& Huggenberger 2007). Another thirteen springs were situated in other parts of the Jura Mountains (see Tab. 1). For this study we selected the 25 least-disturbed (of 82) springs investigated from 2003-2005 by the Basel Spring Project (Baltes et al. 2005), based on the evaluation method of Hotzy et al. (2003). They are all in a natural, or at least near-natural, condition, only Q4 and dam are channelled. Natural springs in the Swiss Jura are almost exclusively found in forested areas (Zollhöfer 1997), and most of the springs in this study are situated in managed forest, at the edge of the forest, or in non-native Thuja forest; only two are in grassland. The Jura Mountains are a pre-Alpine, low mountain range, with limestone as the main geological substratum and the springs are $350-540 \mathrm{~m}$ a.s.l. During the study period, from autumn 2003 to summer 2005, no severe changes, such as clearings or sudden nutrient input occurred around or in the springs. However, due to forest management, slight changes were evident in the woods around the springs during this period, but they did not affect the light regime of the adjacent springs.

\subsection{Macroinvertebrate sampling}

Macroinvertebrates were sampled quantitatively with a small surber sampler $\left(0.01 \mathrm{~m}^{2}, 500 \mu \mathrm{m}\right.$ mesh width) following Von Fumetti et al. (2006). On every sampling occasion four spatial replicates were taken in each spring, less than $5 \mathrm{~m}$ from the source (sampling area per sampling occasion: $0.04 \mathrm{~m}^{2}$ ). All springs were sampled at least twice (12 springs), some of them on three (7 springs), four (5) or even five (1) occasions from 2003-2007. This resulted in 8-20 samples per crenon.

After separating out Turbellaria for live identification, all samples were immediately preserved in $70 \%$ ethanol in the field, and subsequently sorted and determined in the laboratory. Taxonomically demanding Dipteran groups (e.g., Chironomidae) were identified to family level, all others were identified to the most precise taxonomic level, e.g. species or genera level. The focus of this survey was the macrozoobenthos. The meiofaunal taxa, Ostracoda, Copepoda and Hydracarina, 
Tab. 2. Abundance and number of ispecies in the respective functional feeding groups characterising the different springs, and species parameters characterising the springs; No. = number; in bold = functional feeding group characterising the spring

\begin{tabular}{|c|c|c|c|c|c|c|c|c|c|c|}
\hline & \multicolumn{2}{|c|}{ Gatherers/ shredders } & \multicolumn{2}{|c|}{ Filtering collectors } & \multicolumn{2}{|c|}{ Scrapers } & \multirow[b]{2}{*}{$\begin{array}{c}\text { Total ind. } \\
\text { Species }\end{array}$} & \multirow[b]{2}{*}{$\begin{array}{c}\text { Species } \\
\text { richness }\end{array}$} & \multirow[b]{2}{*}{$\begin{array}{l}{[\%] \text { ind. }} \\
\text { Species }\end{array}$} & \multirow[b]{2}{*}{$\begin{array}{l}\text { Shannon } \\
\text { diversity }\end{array}$} \\
\hline & Abundance & $\begin{array}{l}\text { No. ind. } \\
\text { Species }\end{array}$ & Abundance & $\begin{array}{l}\text { No. ind. } \\
\text { Species }\end{array}$ & Abundance & $\begin{array}{l}\text { No. ind. } \\
\text { Species }\end{array}$ & & & & \\
\hline Q1 & 3.5 & 5 & 0.7 & 2 & 0.5 & 5 & 20 & 24 & 83 & 1.73 \\
\hline Q3 & 8.1 & 4 & 1.2 & 2 & 0.5 & 7 & 26 & 30 & 87 & 1.98 \\
\hline Q4 & 3.8 & 2 & 0.4 & 2 & 12.3 & 6 & 20 & 28 & 71 & 2.12 \\
\hline Q57 & 1.4 & 2 & 0.2 & 2 & 1.1 & 4 & 18 & 23 & 78 & 1.48 \\
\hline Q59a & 1.8 & 3 & 1.1 & 3 & 6.4 & 6 & 24 & 29 & 83 & 1.87 \\
\hline Q59b & 3.2 & 3 & 0.6 & 5 & 12.6 & 5 & 25 & 29 & 86 & 2.08 \\
\hline Q59c & 1.7 & 4 & 0.3 & 3 & 11.4 & 6 & 24 & 30 & 80 & 2.12 \\
\hline Q61a & 5.7 & 4 & 6.1 & 4 & 0.2 & 2 & 22 & 29 & 76 & 2.28 \\
\hline Q61b & 4.7 & 5 & 0.2 & 1 & 1.4 & 4 & 17 & 23 & 74 & 1.99 \\
\hline Q62 & 8.0 & 3 & 1.4 & 3 & 0.2 & 4 & 24 & 27 & 89 & 1.79 \\
\hline Q63 & 10.0 & 2 & 0.9 & 1 & 31.5 & 4 & 20 & 24 & 83 & 1.96 \\
\hline Q64 & 8.9 & 3 & 21.3 & 3 & 0.5 & 1 & 18 & 22 & 82 & 2.22 \\
\hline erl & 29.2 & 5 & 31.5 & 3 & 0.6 & 2 & 18 & 21 & 86 & 2.25 \\
\hline non & 8.2 & 4 & 0.8 & 2 & 0.4 & 3 & 20 & 22 & 91 & 2.06 \\
\hline dam & 27.4 & 4 & 30.8 & 1 & 1.1 & 2 & 12 & 15 & 80 & 1.41 \\
\hline isch & 14.4 & 3 & 0.4 & 2 & 0.1 & 1 & 13 & 17 & 76 & 1.81 \\
\hline chr1 & 6.7 & 3 & 56.8 & 4 & 195.3 & 6 & 21 & 26 & 81 & 1.45 \\
\hline chr2 & 7.4 & 3 & 10.4 & 2 & 121.4 & 6 & 19 & 25 & 76 & 1.89 \\
\hline flu & 7.1 & 1 & 1.3 & 2 & 111.3 & 6 & 17 & 19 & 89 & 1.75 \\
\hline düb & 4.9 & 4 & 0.1 & 1 & 5.9 & 3 & 19 & 22 & 86 & 1.60 \\
\hline gor & 4.8 & 1 & 11.5 & 1 & 0.6 & 4 & 13 & 18 & 72 & 1.50 \\
\hline lup & 4.5 & 4 & 0.3 & 1 & 30.6 & 4 & 14 & 20 & 70 & 1.83 \\
\hline tbr & 6.3 & 3 & 3.8 & 2 & 157.8 & 7 & 21 & 25 & 84 & 1.98 \\
\hline grei & 10.6 & 2 & 7.1 & 3 & 7.1 & 5 & 17 & 21 & 81 & 1.88 \\
\hline mari & 13.8 & 1 & 0.3 & 3 & 0.8 & 3 & 11 & 15 & 73 & 1.88 \\
\hline
\end{tabular}

were only caught accidentally. However, as we used the same sampling procedure for every spring, we did not exclude them from our statistical analyses. A test exclusion did not alter the results of our analysis. For further analyses the average abundance of all individual taxa in the 8-20 samples per crenon was calculated.

For each taxon (genus or species) the functional feeding group was determined based on Moog (1995) and the Bayerisches Landesamt für Wasserwirtschaft (1996): shredders, gathering collectors, scrapers, filtering collectors, predators, mixed feeders or parasites. The average abundance of classified taxa was summed for each functional feeding group (in the following: FFGs) at each site. Gammarus fossarum was excluded from the calculation because of its high frequency in most of the springs, due to its widespread occurrence in almost every headwater in the region. The most abundant FFG, with the highest average number of individuals, was used to categorise each crenon. Gathering collectors and shredders were pooled as one group (Tab. 2). Since species abundance is more important than species diversity for turnover rates, we did not consider species richness within the FFGs.

\subsection{Abiotic measurements}

On each macrofaunal sampling occasion, water temperature $\left({ }^{\circ} \mathrm{C}\right), \mathrm{pH}$ value, conductivity $\left(\mu \mathrm{S} \mathrm{cm}{ }^{-1}\right)$, oxygen concentration (mg L ${ }^{-1}$ ), and oxygen saturation (\%) were recorded in the field using portable meters (Wissenschaftlich-Technische Werkstätten, Weilheim, Ger- many). In addition, where possible, discharge was estimated by measuring the volume of water entering a plastic bag in five seconds (after Zollhöfer 1999). As such measurements were not possible in springs with diffuse or large-area discharge, we did not consider discharge for further statistical analyses. As all the springs are very similar in their physical and chemical characteristics, these parameters had no influence on macroinvertebrate assemblages (Von Fumetti et al. 2006), and were not considered in this study.

The substratum types, bryophytes, leaf litter, wood, leaf packs, roots, FPOM (Fine Particulate Organic Matter), macrophytes, anoxic mud, clay/silt, sand, gravel, stones, blocks and carbonate precipitates, were categorized visually into five frequency classes: $0: 0 \%$; 1: 1-25\%; 2: 26-50\%; 3: 51-75\%; 4: 76-100\% in every crenon (Hahn 2000; Von Fumetti et al. 2006). Because of the three-dimensional structure of the streambed, the percentages of substratum types usually totalled more than $100 \%$.

\subsection{Statistical analysis}

All statistical analyses below were performed using PRIMER 6.0 (Clarke \& Gorley 2006). For the faunistic data the Bray-Curtis similarity with square root - transformation was used. Substratum data was neither normalized nor transformed, and the Euclidian distance was used as a measure of similarity. Ordination of the springs was conducted using non-metric multidimensional scaling (nMDS). The analysis of similarities-pro- 
cedure (ANOSIM), which is analogous to ANOVA, but relies on a similarity matrix and makes a minimum of assumptions, e.g. no balanced replication, (Clarke \& Gorley 2006) was used to test the grouping of the springs. The group factor was the dominant, i.e. most abundant FFG: filtering collectors, scrapers or gathering collectors/ shredders dominated. Detailed information about nMDS and ANOSIM is given in Von Fumetti et al. (2007). In addition a principal components analysis was performed with the substratum data to determine the most important substratum types characterizing the springs. The factor loadings can be interpreted as correlations between the variables and factors.

Using the SIMPER-procedure, dissimilarities between, and similarities within, groups can be explained with individual species and the composition of the macroinvertebrate assemblages. Species discriminating groups contribute more or less consistently to the distinction of two groups, with a low ratio of average dissimilarity (diss) and standard deviation (SD). Species typical for a group contribute highly to the similarity within a group and have a consistently strong presence (high ratio diss/SD). The group factor was the dominant FFG: filtering collectors, scrapers, gathering collectors/shredders.

\section{RESULTS}

All sites are cold-temperate springs with an average temperature of $7-11^{\circ} \mathrm{C}$ throughout the year (Tab. 1). In some the temperature decreased to $<5{ }^{\circ} \mathrm{C}$ in winter or rose to $>16{ }^{\circ} \mathrm{C}$ in summer, giving a relatively high amplitude, whereas most of the springs had temperature amplitudes of $1-4{ }^{\circ} \mathrm{C}$. All springs were circumneutral $(\mathrm{pH}$ 7.2-8.4) and were nearly saturated with oxygen (more than 90\%) on the sampling occasions. The electrical conductivity was between 200 and $750 \mu \mathrm{S} \mathrm{cm}^{-1}$. Only the helocrene spring erl was slightly acidic (5.56.8) and of low conductivity (45-85 $\left.\mu \mathrm{S} \mathrm{cm}^{-1}\right)$. Discharge was between $210 \mathrm{~L} \mathrm{~min}^{-1}$ (mari) and $<1 \mathrm{~L} \mathrm{~min}^{-1}$ (Q64, erl), with the highest amplitude in mari (168).

A total of 68 species and higher taxa, among them 17 Trichoptera species, were recorded. Gammarus fossarum Koch, 1835 was the most abundant species, occurring in almost every spring at high densities. On average, 23 taxa were found in each crenon (15-30) and the Shannon diversity was between 1.5 (dam) and 2.3 (Q61a, erl) (Tab. 1).

Ordination of the faunistic data based on taxon abundance shows a grouping of springs reflecting the dominant FFGs: filtering collectors, scrapers and gathering collectors/ shredders (Fig. 1).

The substratum types also revealed a crenon grouping based on the dominant FFGs, and significantly different with ANOSIM (Global Test: $R=0.431 ; p=$ 0.001 ) (Fig. 2). The highest and most significant difference (Pairwise Test: $R=0.611 ; p=0.002$ ) was between the scraper- and the filtering collector-dominated springs.

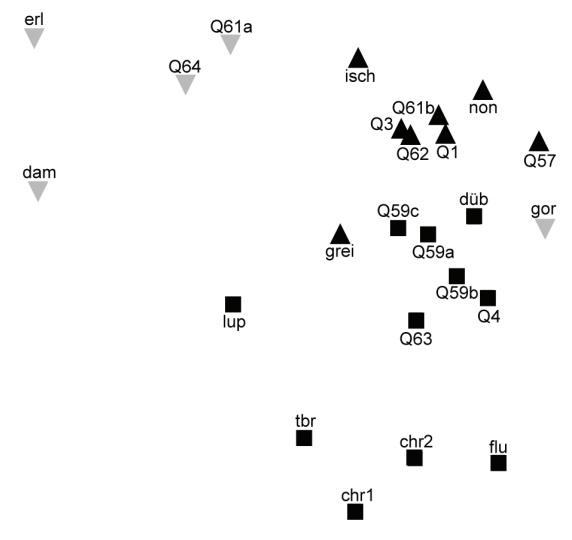

Fig. 1. Non-Metric Multidimensional Scaling (nMDS) of the springs based on the average faunistic data; similarity index: Bray-Curtis, transformation: square root; factor: dominant functional feeding group, stress: $0.16 ; \boldsymbol{\nabla}=$ filtering collectors dominated; $\mathbf{-}=$ scrapers dominated; $\boldsymbol{\Delta}=$ gathering collectors/shredders dominated.

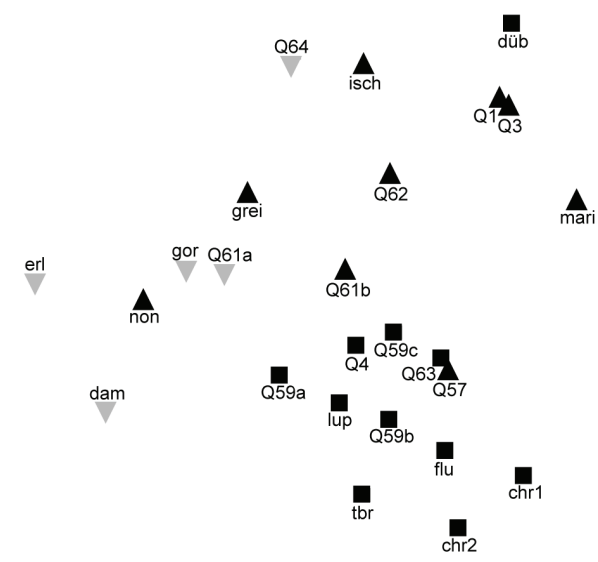

Fig. 2. Non-Metric Multidimensional Scaling (nMDS) based on the substratum type of the springs; similarity index: Euclidian Distance, transformation: none; factor: dominant functional feeding group, stress: $0.15 ; \boldsymbol{\nabla}=$ filtering collectors dominated; $\boldsymbol{\boldsymbol { v }}=$ scrapers dominated; $\boldsymbol{\Delta}$ = gathering collectors/shredders dominated; Analysis of similarities (ANOSIM): Global test: $R=0.431, p=0.001$; Pairwise test: filtering collectors - gathering collectors/shredders: $R=0.303, p=0.026$, filtering collectors - scrapers: $R=0.611, p=0.002$, gathering collectors/shredders - scrapers: $R=0.38, p=0.002$.

The principal components analysis conducted on the substratum data showed that PC axes one (eigenvalue: 3.54 ) and two (eigenvalue: 3.06) explained 28 and $25 \%$ of the variance, respectively. The first three PC axes together explained $64 \%$ of the variance. PC1 is positively loaded by carbonate deposits and crusts (eigenvector: 0.852 ) and negatively by small stones (eigenvector: -0.216). PC2 is positively loaded by clay/silt (eigenvector: 0.544) and leaves (eigenvector: 0.326) and negatively by bryophytes (eigenvector: -0.314 ), small stones (eigenvector: -0.375) and gravel (eigenvector: -0.273 ). Scraper-dominated springs show a high negative load on both PC1 and PC2 axes; they are dominated 


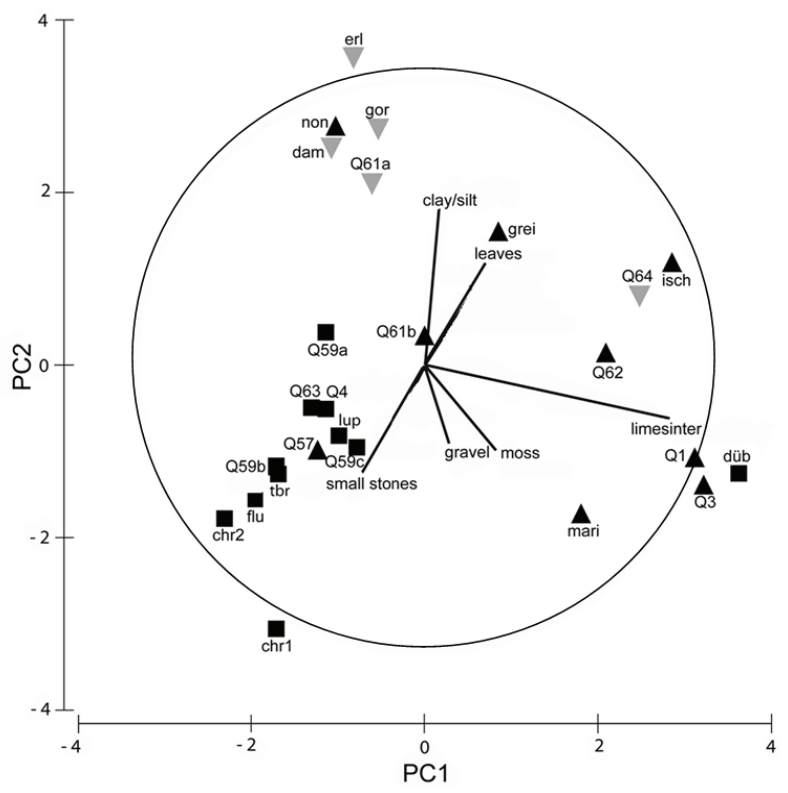

Fig. 3. Principal components analysis (PCA) of the substratum types. Lines: vector length of the superimposed eigenvectors of the most important substratum type, circle = highest possible contribution of a factor to an axis (=1); Factor = dominant functional feeding group; $\boldsymbol{\nabla}=$ filtering collectors dominated; $\boldsymbol{\boldsymbol { a }}=$ scrapers dominated; $\boldsymbol{\Delta}$ = gathering collectors/shredders dominated.

by coarse substrata. Filtering collector-dominated springs are dominated by clay and decaying plant material (PC2, positive load), while the gathering collectors/shredder-dominated springs are strongly influenced by carbonate deposits (PC1, positive load) (Fig. 3).

Using SIMPER we calculated the faunal assemblage similarity within each crenon group and identified key species. Most also occur in other groups but at lower densities. Scraper-dominated springs (similarity: 53\%) are characterized by Synagapetus dubitans McLachlan, Elmis rietscheli Stefan, and Bythiospeum spp., which are typical of lotic environments. Pisidium cf. personatum Malm occurs at high densities in those springs dominated by filtering collectors (similarity: 45\%). The gathering collectors and shredders, e.g. Oligochaeta and Nemoura spp., attained high densities in the third group (similarity: 59\%).

\section{DISCUSSION}

Since the beginning of ecological research into springs the differentiation of distinct crenon types has been a focus of interest. Steinmann (1915) and Thienemann (1924) differentiated springs into rheocrenes, helocrenes and limnocrenes, but it soon became obvious that this tripartite division oversimplified the situation, and that crenon type depends on many environmental factors, particularly the geological and geographical context. As a consequence, the habitat-related morphological classification of springs was extended for several mid-European regions (Schwoerbel 1959; Gerecke 1991; Zollhöfer 1997; Hahn 2000), all typologies being based on the classical triad (Zollhöfer 1997), with the modifications of Schwoerbel (1959) and Gerecke (1991) being the most widely applied (e.g., Di Sabatino et al.
2003; Gerecke et al. 2005; Sambugar et al. 2006). Taking into account the existing crenon typologies, we consider that there is a continuous transition between the traditional ecomorphological types (Von Fumetti et al. 2006), the identification of which is difficult, dependent on the local geology and not necessarily showing characteristic crenic assemblages. Rather than using ecomorphology, a faunistic approach to crenon classification is promising and has the advantage that organisms function as indicators of the abiotic features of the springs. Some attempts have been made to include fauna in the classification of springs, and to verify a priori-defined ecomorphological types with faunistic data (a posteriori) (Weigand 1998, unpublished report; Schröder et al. 2006; Dumnicka et al. 2007). Ilmonen \& Paasivirta (2005) discriminated lentic, lotic and intermediate crenic sites within springs, supporting Thienemann's (1924) typology. Zollhöfer et al.'s (2000) study is most important for Switzerland and adjacent regions; this regional typology is based on habitat variables and faunistic parameters. The first attempt to develop an a priori faunistic crenon typology was by Gauterin (1996), based on faunistic evaluation concepts (Fischer 1996) and plant sociology (e.g., Dierschke 1994). Ilmonen et al. (2009) classified springs faunistically a posteriori, but a priori within different ecoregions, and identified indicator species that discriminated two crenic groups on a large scale.

We identified FFGs dominating different springs and classified the springs, a priori, based on the FFGs. Our study confirms that the macroinvertebrate assemblages of springs are characterised by dominant FFGs that reflect the habitat qualities of the individual springs, especially substratum type. Substratum composition 
(Dumnicka 2007), discharge (Smith 2003; Von Fumetti et al. 2006) or both (Minshall 1968; Bonettini \& Cantonati 1996; Mori \& Brancelj 2006) have been documented as factors influencing the composition of crenic macroinvertebrate assemblages.

The trophic structuring of stream communities into FFGs (Cummins 1973; Cummins \& Klug 1979) is a well-established ecological concept which allows a complex benthic community to be divided into distinct components, based on particle size ingested and mouthpart morphology (Mihuc 1997). In riparian-dominated headwater-streams there are also linkages between CPOM (Coarse Particulate Organic Matter) and shredders, FPOM and collectors, and periphyton and scrapers (Merritt \& Cummins 1984). Functional feeding groups also underpin the River Continuum Concept (Vannote et al. 1980), which proposes that collectors and shredders codominate headwaters that are influenced by riparian vegetation. There are several studies describing trophic relationships in individual springs, especially limnocrenes (e.g., Odum 1957; Teal 1957; Tilly 1968), which all indentified allochthonous leaf material as the main food source for the herbivores (e.g., Minshall 1968; Stern \& Stern 1969; Teal 1957). Furthermore, the Gammaridae also play an important role in springs, as shredders, by decomposing the allochthonous leaf material (Iversen 1988; Glazier 1991; Barquin \& Death 2004). Gammarus fossarum was by far the most abundant organism in our springs. There are only a few comparative studies involving trophic structure in springs (Glazier 1991; Hoffsten \& Malmqvist 2000) or spring-streams (Gaines et al. 1989; Cushing 1996), and there has been no attempt to combine FFGs into crenon classification. Only Hoffsten \& Malmqvist (2000) compared the trophic structure of geologically different springs a posteriori.

The crenon group dominated by scrapers such as Synagapetus dubitans and Elmis rietscheli were dominated by coarse inorganic substrata. They can be treated as lotic springs in which the amount of leaf litter is low, probably as a result of the high, constant discharge in these springs. They also provide a lot of coarse substratum for periphyton, an autochthonous food source. We postulate that lotic springs are generally characterized by scrapers like Synagapetus spp. and Elmis spp. The high and, more significantly constant, discharge is important for the specialized, sensitive scrapers, which are usually more sensitive to pollution and disturbance than the generalists, filtering collectors and gathering collectors (Merritt \& Cummins 1984; Rawer-Jost et al. 2000).

Filtering collectors like Pisidium spp. have been identified as typical of springs dominated by organic substrata and clay, and exhibiting low discharge. Here, the input of allochthonous material, which is then converted into CPOM and finally FPOM, is more important and constant (Cummins \& Klug 1979). We treat such springs as lentic springs, similar to helocrenes, which do not naturally exist in the Jura Mountains (Zollhöfer
1997), but are plentiful in northern Europe (Lindegaard 1998; Ilmonen \& Paasivirta 2006) and also in low, siliceous mountain ranges in Central Europe (Beierkuhnlein \& Gräsle 1998; Strohbach et al. 2009). In "true" helocrenes, autochthonous material such as bryophytes and macrophytes is more important (Lindegaard et al. 1998; Ilmonen \& Paasivirta 2005).

Springs with a lot of associated limestones, forming terraces or calcite stairs (Zollhöfer et al. 2000), are typical for the Swiss Jura and other lime-dominated regions. Because of their high $\mathrm{CaCO}_{3}$-content they create different conditions, under which collector-gatherers and shredders dominate the species assemblages. Since collectors and shredders have been identified as key FFGs, we believer that the terraces function as FPOM and CPOM sinks. This also explains the sometimes high abundance of predatory salamander larvae in the pondlike habitats, (see also Zollhöfer 1997). The calcareous tufa springs offer a variety of microhabitats, both lotic and lentic sections, which may favour the generalist collector-gatherers. The spectrum of springs in the Swiss Jura ranges from lotic springs dominated by scrapers to lentic springs dominated by filtering collectors. All other crenon types are transitional forms, offering a mosaic of habitat types (Fig. 4). Such intermediate forms with many different microhabitats may have especially high diversity (Di Sabatino et al. 2003), but. the mixed environment springs with many microhabitats in our study did not have the highest diversity.

Our results show that springs can be classified on the composition of different FFGs, which reflect characteristic faunistic assemblages or even biocoenoses. They are an integrative measure of the abiotic features and a measure of functional diversity in springs. The main goal for future research will be to develop regional faunistic classifications based on functional feeding groups for each landscape unit, and to transfer this to a broader scale. Autecological research is still required to improve assignments to FFGs (Rawer-Jost et al. 2000). We will then be able to develop a faunistic crenon typology for the entire Swiss Alpine and Pre-Alpine region, and for adjacent areas such as the geologically very different, Black Forest in Germany. Such a typology will be transferable to other European regions with similar conditions.

\section{CONCLUSIONS}

Springs in the Swiss Jura Mountains were classified faunistically using the dominant functional feeding groups. These reflect the abiotic features of the springs, especially substratum composition, which is determined by the discharge regime. We can now distinguish between springs dominated by scrapers, characterized by a lotic environment, and those, which are mostly inhabited by filtering collectors, associated with a lentic environment. Calcareous tufa springs are characterized by gathering collectors and shredders. In future this approach will be expanded to other pre-Alpine and 


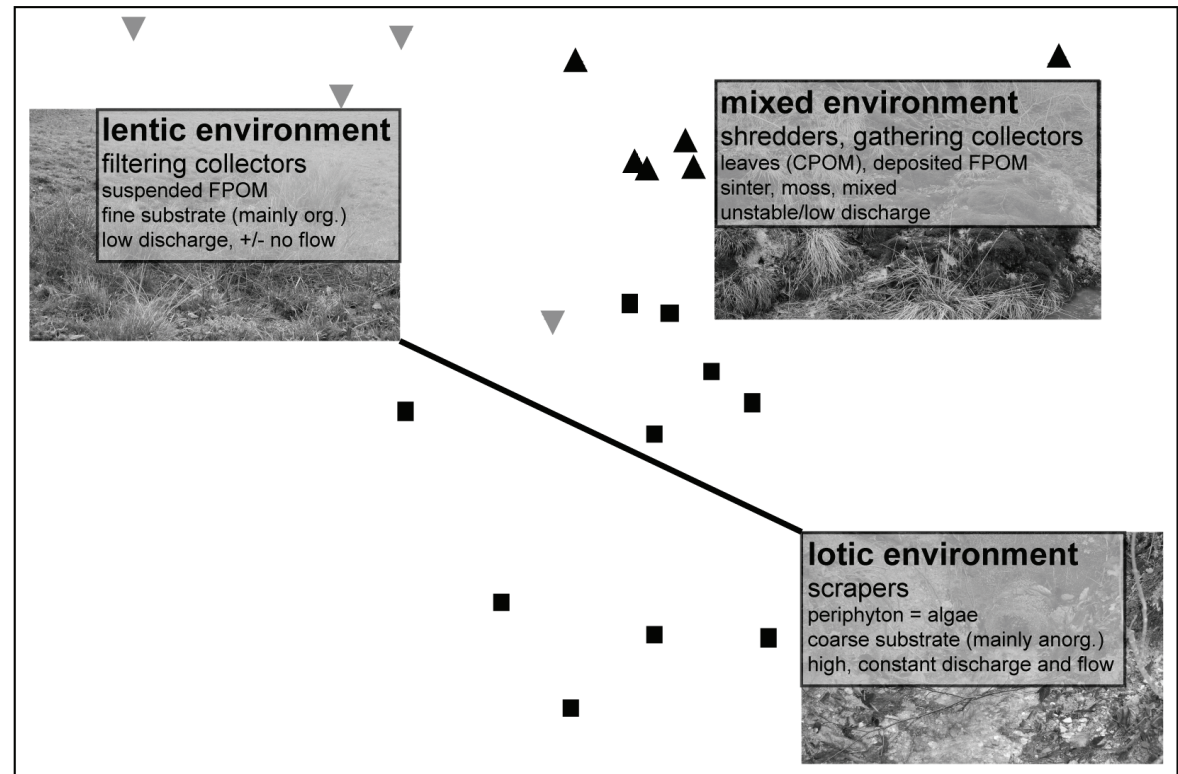

Fig. 4. Spectrum of springs in Mid-European regions inhabited by characteristic biocoenoses dominated by functional feeding groups. Black Line: the transition from one extreme to the other; background: nMDS of the springs based on the average faunistic data. FFGs = Functional Feeding Groups, CPOM = Coarse Particulate Organic Matter, FPOM = Fine Particulate Organic Matter.

Alpine regions in Switzerland and adjacent regions. We will then have a valuable tool for characterising crenic ecosystems and assessing their ecological status.

\section{ACKNOWLEDGEMENTS}

We thank the MGU program and the Freiwillige Akademische Gesellschaft (FAG) of the University of Basel for funding the project, and the Drinking Water Laboratory for its financial and technical support. We acknowledge numerous people who helped with the fieldwork throughout the years. We thank Peter Martin for identifying Acari and Rüdiger Wagner for identifying Psychodidae.

\section{REFERENCES}

Baltes, B., S. von Fumetti, D. Küry, E. Contesse, C. Butscher, P. Huggenberger, D. Suter, W. Leimgruber \& P. Nagel. 2005. Basel entdeckt seine Quellen. In: Deutsche Gesellschaft für Limnologie, Proceedings 2004: 226-230.

Baltes, B., S. von Fumetti \& P. Nagel. 2006. Quellen, die verlorenen Biotope? In: Deutsche Gesellschaft für Limnologie, Proceedings 2005: 30-34.

Barquin, J. \& R.G. Death. 2004. Patterns of invertebrate diversity in streams and freshwater springs in Northern Spain. Arch. Hydrobiol., 161: 329-349.

Bayerisches Landesamt für Wasserwirtschaft (Ed.). 1996. Ökologische Typisierung der aquatischen Makrofauna. Informationsberichte, 4.

Beierkuhnlein, C. \& W. Gräsle 1998. The influence of light regime and water chemistry on the structure of forest spring vegetation. In: L. Botosaneanu (Ed.), Studies in crenobiology. The biology of springs and springbrooks. Backhuys Publishers, Leiden: 9-22.

Beyer, H. 1932. Die Tierwelt der Quellen und Bäche des Baumberggebietes. Abh. Westfäl. Prov.-Mus. Nat. kunde, 3: 9-189.

Bonettini, A.M. \& M. Cantonati. 1996. Macroinvertebrate assemblages of springs of the River Sarca catchment (Adamello-Brenta Regional Park, Trentino, Italy). Crunoecia, 5: 71-78.
Bornhauser, K. 1912. Die Tierwelt der Quellen in der Umgebung Basels. Internat. Rev. Ges. Hydrobiol., Biol. Suppl., 5: 1-90.

Butscher, C. \& P. Huggenberger. 2007. Implications for karst hydrology from 3D geological modelling using the aquifer base gradient approach. J. Hydrol., 342: 184-198.

Cantonati, M. 2004. Le diatomee di tre sorgenti del Parco delle Prealpi Giulie. Gortania, 25: 89-102.

Chappuis, P.A. 1924. Die Fauna der unterirdischen Gewässer der Umgebung von Basel. Arch. Hydrobiol., 14: 1-88.

Clarke, K.R. \& R.N. Gorley. 2006. PRIMER v6: user manual. PRIMER-E, Plymouth: 190 pp.

Cummins, K.W. 1973. Trophic relations of aquatic insects. Ann. Rev. Ent., 18: 183-206.

Cummins, K.W. \& M.J. Klug. 1979. Feeding ecology of stream invertebrates. Ann. Rev. Ecol. Syst., 10: 147-172.

Cushing, C.E. 1996. The ecology of cold desert springstreams. Arch. Hydrobiol., 135: 499-522.

Dierschke, H. 1994. Pflanzensoziologie. Ulmer, Stuttgart: 683 pp.

Di Sabatino, A., B. Cicolani \& R. Gerecke. 2003. Biodiversity and distribution of water mites (Acari, Hydrachnidia) in spring habitats. Freshwat. Biol., 48: 2163-2173.

Dumnicka, E., J. Galas \& P. Koperski. 2007. Benthic invertebrates in karst springs? Does substratum or location define communities? Internat. Rev. Hydrobiol., 92: 452-464.

Ferrington, L.C. 1995. Biodiversity of aquatic insects and other invertebrates in springs: Introduction. J. Kans. Entomol. Soc., 68: 1-3.

Fischer, J. 1996. Bewertungsverfahren zur Quellfauna. Crunoecia, 5: 227-240.

Gaines, W.L., C.E. Cushing \& S.D. Smith. 1989. Trophic relations and functional group composition of benthic insects in three cold desert streams. Southwest. Natural., 34: 478-482.

Gauterin, H. 1999. Vorschlag zu einer überregionalen faunistischen Quelltypologie mit einer Beschreibung der Crenobia alpina-Bythinella dunkeri-Zoozönose. Crunoecia, 6: 67-72.

Geijskes, D.C. 1935. Faunistisch-ökologische Untersuchungen am Röserenbach bei Liestal im Basler Tafeljura. Beiträge zur Ökologie der Mittelgebirgsbäche. Tijdschr. Entomol., 78: 249-382. 
Gerecke, R. 1991. Taxonomische, faunistische und ökologische Untersuchungen an Wassermilben aus Sizilien unter Berücksichtigung anderer aquatischer Invertebraten. Lauterbornia, 7: 304 pp.

Gerecke, R. \& A. Di Sabatino. 1996. Water mites (Acari, Hydrachnellae) and spring typology in Sicily. Crunoecia, 5: $35-42$.

Gerecke, R., F. Stoch, C. Meisch \& I. Schrankel. 2005. Die Fauna der Quellen und des hyporheischen Interstitials in Luxemburg. Ferrantia, 41: 140 pp.

Glazier, D.S. 1991. The fauna of North American temperate cold springs: patterns and hypotheses. Freshwat. Biol., 26: 527-542.

Hahn, H.J. 2000. Studies on classifying of undisturbed springs in Southwestern Germany by macrobenthic communities. Limnologica, 30: 247-259.

Hoffsten, P.-O. \& B. Malmqvist. 2000. The macroinvertebrate fauna and hydrogeology of springs in central Sweden. Hydrobiologia, 436: 91-104

Ilmonen, J. \& L. Paasivirta. 2005. Benthic macrocrustacean and insect assemblages in relation to spring habitat characteristics: patterns in abundance and diversity. Hydrobiologia, 533: 99-113

Ilmonen, J., L. Paasivirta, R. Virtanen \& T. Muotka. 2009. Regional and local drivers of macroinvertebrate assemblages in boreal springs. J. Biogeogr., 36: 822-834.

Iversen, T.M. 1988. Secondary production and trophic relationships in a spring invertebrate community. Limnol. Oceanogr., 33: 582-592.

Küry, D. 1997. Changes in the Ephemeroptera and Plecoptera populations of a Swiss Jura stream (Röserenbach) between 1935 and 1990. In: P. Landolt \& P.M. Sartori (Eds), Ephemeroptera and Plecoptera: Biology-Ecology-Systematics. MTL, Fribourg: 296-301.

Lindegaard, C., K.P. Brodersen, P. Wiberg-Larsen \& J. Skriver. 1998. Multivariate analyses of macrofaunal communities in Danish springs and springbrooks. In: L. Botosaneanu (Ed.), Studies in crenobiology. The biology of springs and springbrooks. Backhuys Publishers, Leiden: 201-219.

Martin, P., M. Rückert \& M. Brunke. 2008. Eine faunistisch begründete Quelltypologie für Schleswig-Holstein. In: Deutsche Gesellschaft für Limnologie. Proceedings 2007: 74-78.

Merritt, R.W. \& K.W. Cummins. 1984. An introduction to the aquatic insects of North America. Kendall/Hunt Publ., Dubuque: $722 \mathrm{pp}$.

Mihuc, T.B. 1997. The functional trophic role of lotic primary consumers: generalist versus specialist strategies. Freshwat. Biol., 37: 455-462.

Minshall, G.W. 1968. Community dynamics of the benthic fauna in a woodland springbrook. Hydrobiologia, 32: 305-339.

Moog, O. 1995. Fauna Aquatica Austriaca. Wasserwirtschaftskataster. Bundesministerium für Land- und Forstwirtschaft, Wien.

Mori, N. \& A. Brancelj. 2006. Macroinvertebrate communities of karst springs of two river catchments in the Southern Limestone Alps (the Julian Alps, NW Slovenia). Aquat. Ecol., 40: 69-83.

Odum, H.T. 1957. Trophic structure and productivity of Silver Springs, Florida. Ecol. Monogr., 27: 592-597.

Odum, E.P. 1971. Fundamentals of Ecology. Saunders, Philadelphia: 574 pp.

Rawer-Jost, C., J. Böhmer \& H. Rahmann. 2000. Macroinvertebrate functional feeding group methods in ecological assessment. Hydrobiologia, 422/423: 225-232.

Roca, J.R. 1990. Tipologia fisico-quimica de las Fuentes de los Pireneos centrales: sintesis regional. Limnetica, 6: 57-78.

Sambugar, B., G. Dessi, A. Sapelza, A. Stenico, B. Thaler \& A. Veneri. 2006. Südtiroler Quellfauna. Autonome Provinz Bozen: 365 pp.
Schröder, H., H. Howein \& R. Gerecke. 2006. Quelltypen und Quellfauna. In: R. Gerecke \& H. Franz (Eds), Quellen im Nationalpark Berchtesgaden, Nationalpark Berchtesgaden. Forschungsbericht 51: 214-220.

Schwörbel, J. 1959. Ökologische und tiergeographische Untersuchungen über die Milben (Acari, Hydrachnellae) der Quellen und Bäche des südlichen Schwarzwaldes und seiner Randgebiete. Arch. Hydrobiol., Suppl. 24: 385-546.

Smith, H., P.J. Wood \& J. Gunn. 2003. The influence of habitat structure and flow permanence on invertebrate communities in karst spring systems. Hydrobiologia, 510: 53-66.

Steinmann, P. 1915. Praktikum der Süßwasserbiologie. Bornträger, Berlin: $184 \mathrm{pp}$.

Stern, M.S. \& D.H. Stern. 1969. A limnological study of a Tennessee cold springbrook. Am. Midl. Nat., 82: 62-82.

Strohbach, M, V. Audorff \& C. Beierkuhnlein 2009. Drivers of plant species composition in siliceous spring ecosystems: groundwater chemistry, catchment traits or spatial factors? J. Limnol., 68: 375-384

Teal, J.M. 1957. Community metabolism in a temperate cold spring. Ecol. Monogr., 27: 283-302.

Thienemann, A. 1912. Der Bergbach des Sauerlandes. Faunistisch-biologische Untersuchungen. Internat. Rev. Ges. Hydrobiol., Biol. Suppl. 4: 1-125.

Thienemann, A. 1923. Hydrobiologische Untersuchungen an Quellen V. Die Trichopterenfauna der Quellen Holsteins. Z. Wiss. Insektenbiol., 18: 126-134.

Thienemann, A. 1924. Hydrobiologische Untersuchungen an Quellen. Arch. Hydrobiol., 14: 151-190.

Thienemann, A. 1926. Hydrobiologische Untersuchungen an kalten Quellen und Bächen der Halbinsel Jasmund auf Rügen. Arch. Hydrobiol., 17: 221-331.

Tilly, L.J. 1968. The structure and dynamics of cone spring. Ecol. Monogr., 38: 169-197.

Van der Kamp, R.O. 1995. The hydrogeology of springs in relation to the biodiversity of spring fauna: a review. In: L.C. Ferrington (Ed.), Biodiversity of aquatic insects and other invertebrates in springs. J. Kans. Entomol. Soc., 68: 4-17.

Vannote, R.L., G.W. Minshall, K.W. Cummins, J.R. Sedell \& C.E. Cushing. 1980. The River Continuum Concept. Can. J. Fish. Aquat. Sci., 37: 130-137.

Von Fumetti, S., P. Nagel, N. Scheifhacken \& B. Baltes. 2006. Factors governing macrozoobenthic assemblages in perennial springs in north-western Switzerland. Hydrobiologia, 568: 467-475.

Von Fumetti, S., P. Nagel \& B. Baltes. 2007. Where a springhead becomes a springbrook - a regional zonation of springs. Fundam. Appl. Limnol., 169: 37-48.

Williams, D.D., N.E. Williams \& Y. Cao. 1997. Spatial differences in macroinvertebrate community structure in springs in southeastern Ontario in relation to their chemical and physical environments. Can. J. Zool., 75: 1404-1414.

Williams D.D. \& H.V. Danks. 1991. Arthropods of springs: introduction. In: D.D. Williams \& H.V. Danks (Eds), Arthropods of springs, with particular reference to Canada. Memoirs of the Entomological Society of Canada, 155: 3-5.

Zollhöfer, J.M. 1997. Quellen die unbekannten Biotope: erfassen, bewerten, schützen. Bristol-Schriftenreihe, Zürich, Bd. 6: 153 pp.

Zollhöfer, J.M. 1999. Spring biotopes in northern Switzerland: Habitat heterogenity, zoobenthic communities and colonisation dynamics. PhD Thesis, Swiss Federal Institute of Science and Technology, Zürich: 142 pp.

Zollhöfer, J.M., A. Brunke \& T. Gonser. 2000. A typology of springs in Switzerland by integrating habitat variables and fauna. Arch. Hydrobiol., Suppl. 121: 349-376.

Zschokke, F. 1902. Die Tierwelt eines Bergbaches bei Säckingen im südlichen Schwarzwald. Mitt. Bad. Zool. Ver. Karlsruhe, 11/12: 27-41. 